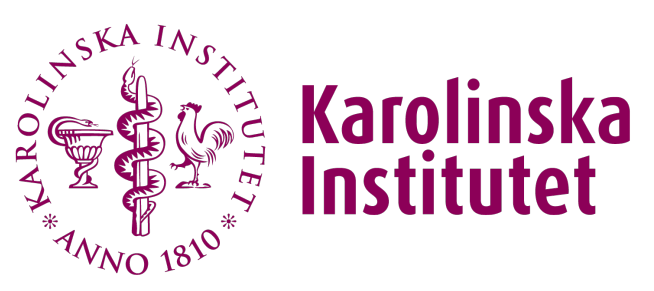

Karolinska Institutet

http://openarchive.ki.se

This is a Peer Reviewed Accepted version of the following article, accepted for publication in Clin Endocrinol (Oxf).

\title{
Are carriers of CYP21A2 mutations less vulnerable to psychological stress? A population-based national cohort study
}

Nordenström, Anna; Butwicka, Agnieszka; Hirschberg, Angelica L; Almqvist, Catarina; Nordenskjöld, Agneta; Falhammar, Henrik; Frisén, Louise

Clin Endocrinol (Oxf). 2017 Mar;86(3):317-324.

http://doi.org/10.1111/cen.13242

http://hdl.handle.net/10616/45952

If not otherwise stated by the Publisher's Terms and conditions, the manuscript is deposited under the terms of the Creative Commons Attribution-NonCommercial-NoDerivatives License (http://creativecommons.org/licenses/by-nc-nd/4.0/), which permits non-commercial re-use, distribution, and reproduction in any medium, provided the original work is properly cited, and is not altered, transformed, or built upon in any way. 


\section{6 \\ Karolinska Institutet}

This is the peer reviewed version of the following article Clin Endocrinol (Oxf). 2017 Mar;86(3):317-324., which has been published in final form at http://dx.doi.org/10.1111/cen.13242

This article may be used for non-commercial purposes in accordance with Wiley Terms and Conditions for SelfArchiving.

Nordenstrom, A.; Butwicka, A.; Linden Hirschberg, A.; Almqvist, C.; Nordenskjold, A.; Falhammar, H.; Frisen, L.

Are carriers of CYP21A2 mutations less vulnerable to psychological stress? A population-based national cohort study. Clin Endocrinol (Oxf). 2017 Mar;86(3):317-324.

DOI: $10.1111 /$ cen.13242

Access to the published version may require subscription. Published with permission from: Wiley 


\section{Are carriers of $C Y P 21 A 2$ mutations less vulnerable to psychological stress? A population-based national cohort study}

Anna Nordenström ${ }^{1,2}$, Agnieszka Butwicka ${ }^{3,4}$, Angelica Lindén Hirschberg ${ }^{1,5}$, Catarina Almqvist $^{3,6}$, Agneta Nordenskjöld ${ }^{1,7,8}$, Henrik Falhammar ${ }^{9,10}$, Louise Frisén ${ }^{11,12}$

${ }^{1}$ Department of Women's and Children's Health, Karolinska Institutet, Stockholm, Sweden

${ }^{2}$ Department of Paediatric Endocrinology, Astrid Lindgren Children's Hospital, Karolinska University Hospital, Stockholm, Sweden

${ }^{3}$ Department of Medical Epidemiology and Biostatistics, Karolinska Institutet, Stockholm, Sweden

${ }^{4}$ Department of Child Psychiatry, Medical University of Warsaw, Warsaw, Poland

${ }^{5}$ Department of Obstetrics and Gynaecology, Karolinska University Hospital, Stockholm,

Sweden

${ }^{6}$ Lung and Allergy Unit, Astrid Lindgren Children's Hospital, Karolinska University Hospital,

${ }^{7}$ Centre for Molecular Medicine, Karolinska Institutet, Stockholm, Sweden

${ }^{8}$ Paediatric Surgery, Astrid Lindgren Children's Hospital, Karolinska University Hospital,

Stockholm, Sweden

${ }^{9}$ Department of Endocrinology, Metabolism and Diabetes, Karolinska University Hospital, Stockholm, Sweden

${ }^{10}$ Department of Molecular Medicine and Surgery, Karolinska Institutet, Stockholm, Sweden

${ }^{11}$ Department of Clinical Neuroscience, Karolinska Institutet, Stockholm, Sweden

${ }^{12}$ Child and Adolescent Psychiatry Research Centre, Stockholm, Sweden

Abbreviated title: An advantage of being a $C Y P 21 A 2$ carrier?

Key words: CYP21A2, CAH, heterozygous, psychiatric diagnosis, stress

Word count: 2983

\section{Corresponding author:}

Associate professor, Senior Consultant

Anna Nordenström

Pediatric Endocrinology

Astrid Lindgren Children's Hospital

Karolinska University Hospital

S-17176 Stockholm

Sweden

Anna.Nordenstrom@ki.se

Disclosure statement: The authors have nothing to disclose 


\begin{abstract}
Background Congenital adrenal hyperplasia $(\mathrm{CAH})$ is one of the most common monogenic autosomal recessive disorders with an incidence of 1 in 15 000. About 1 in 70 individuals in the general population are carriers of a severe CYP21A2 mutation. It has been suggested that this confers a survival advantage, perhaps as a result of increased activity in the hypothalamic-pituitary-adrenal axis. We investigated vulnerability to psychological stress in obligate carriers.
\end{abstract}

Method The Swedish CAH Registry encompasses more than 600 patients. Parents, i.e., obligate carriers of the CYP21A2 mutation, were identified through the Multigeneration Register. The diagnosis of the child was used as the psychological stressor. Psychiatric diagnoses before and after the birth of a child with $\mathrm{CAH}$ were compared to those of controls derived from (i) the general population, (ii) parents of children with hypospadias, and (iii) parents of children with diabetes mellitus type 1 (T1DM).

Results Parents of children with CAH had less risk of being diagnosed with any psychiatric disorder (OR, 0.6), an affective disorder (OR, 0.5) or substance misuse (OR, 0.5) after the diagnosis of the child, compared to the general population. Their risk was also decreased compared to parents of a child with hypospadias (OR, 0.6, 0.4 and 0.2, respectively) and parents of a child with T1DM (OR 0·7, 0.6 and 0.2, respectively). The CYP21A2 carriers had a lower risk of developing mood and stress-related disorders after the diagnosis of the child. Conclusion Obligate $C Y P 21 A 2$ carriers had a reduced risk of a psychiatric diagnosis and were less vulnerable to a psychologically stressful situation, at least with respect to receiving a psychiatric diagnosis. This indicates a better ability to cope with psychological stress among heterozygous carriers of severe $C Y P 21 A 2$ mutations, which may contribute to the apparent survival advantage. 


\section{Introduction}

Congenital adrenal hyperplasia $(\mathrm{CAH})$ due to 21-hydroxylase deficiency is one of the most common monogenic autosomal recessive disorders with an incidence of 1 in 10 000-20 000. ${ }^{1}$ The incidence is even higher in some populations, e.g., 1/295 in Yupik Eskimos (classic $\mathrm{CAH}$ ) and 1/27 in the Ashkenazi Jewish population (non-classic CAH). ${ }^{2}$ About 1 in 50 individuals in the Swedish population are carriers of a mutation in the CYP21A2 gene and 1 in 70 of a classic, more severe, $C Y P 21 A 2$ mutation. ${ }^{3}$ It has been suggested that being a carrier confers a survival advantage that could explain the relatively high frequency of the disease in most worldwide populations, similarly to the situation with sickle cell anemia where carriers have a survival advantage due to resistance to malaria. ${ }^{4,5,6}$

$\mathrm{CAH}$ results in varying degrees of cortisol and adrenalin deficiency. The severity of disease correlates with the severity of the CYP21A2 mutation. Clinically, CAH has been divided into the salt-wasting (SW), simple virilising (SV) and non-classic (NCAH) forms. ${ }^{1}$ Untreated, patients with the classic SW form develop lethal salt crises in the neonatal period while those with the SV form have a less pronounced risk of salt crisis. The cortisol deficiency leads to an increased pituitary ACTH production and results in increased synthesis of the steroid precursors prior to the enzyme block that are converted into androgens. Both SW and SV children with $\mathrm{CAH}$ result in virilisation of external genitalia at birth in children with $46, \mathrm{XX}$ karyotype. The treatment consists of life long replacement therapy with hydrocortisone and in severe cases fludrocortisone. During periods of physical stress such as febrile illness the hydrocortisone dose must be adjusted. In contrast, patients with the less severe NCAH form escape salt crisis and affected females are not virilised at birth. Patients with NCAH often do not come to medical attention until they develop signs of androgen excess over time such as hirsutism or infertility. Men with NCAH remain largely undiagnosed. ${ }^{7}$ 
There is a strong correlation between disease severity and $C Y P 21 A 2$ genotype based on the mildest allele. ${ }^{8,9}$ Deletions and mutations that completely abolish the enzyme activity in the homozygous form or in combination with the slightly less severe I2 splice mutation result in the most severe salt-wasting form of the disease. The I172N mutation is associated with the simple virilising form while V281L or P453S results in NCAH. ${ }^{10}$

Although carriers of CYP21A2 mutations typically do not have clinical symptoms, increased androgen levels have been reported and their hypothalamic-pituitary-adrenal (HPA) axis is functionally affected. ${ }^{4}$ On ACTH stimulation, carriers respond with increased 17hydroxyprogesterone (17-OHP) levels, the metabolite prior to the enzyme block. ${ }^{11}$ Interestingly, the cortisol response to ACTH stimulation has been shown to be more prompt and increased in carriers than in healthy controls. ${ }^{4}$ This increased efficiency of the HPA axis may be caused by an upregulated ACTH activity due to the relative deficiency in cortisol production and the resulting loss of negative feedback inhibition. One interpretation of these results would be that the carriers have fast and brisk response and a relatively quick downregulation of the cortisol synthesis. It has been hypothesised that this increased cortisol response, in response to stress, could enable a more rapid return to homeostasis and hence be advantageous. ${ }^{4}$ This almost doubled capacity to synthesise cortisol on acute stimulation could explain the proposed evolutionary advantage of being a carrier of a CYP21A2 mutation.

It has been shown that $C Y P 21 A 2$ mutation carriers have a lower 24 hour urinary excretion of free cortisol. ${ }^{5}$ It has been hypothesized that the mild cortisol deficiency can result in a compensatory increase in hypothalamic CRH secretion. CRH is involved in the regulation of the HPA axis but also in other responses to stress such as the autonomic, immune, and 
behavioral responses. $\mathrm{CRH}$ is important for mood and anxiety since it interacts with the amygdala and modulates the monoaminergic system. ${ }^{12,13}$ It is known that cortisol and CRH are increased in anxiety and depression. ${ }^{14,15,16}$ Thus, an increased CRH level could have negative effects. It was therefore suggested that increased CRH may result in vulnerability to anxiety and depression by Charmandari and co-workers who showed that CRH stimulation in CYP21A2 carriers resulted in a higher peak ACTH. They report that a lower cortisol excretion and a higher $\mathrm{ACTH}$ response in 18 obligate $C Y P 21 A 2$ carriers and 16 controls were associated with a predisposition to obsessive-compulsive behavior as assessed by psychometric questionnaires. $^{5}$

The aim of this study was to investigate the vulnerability to psychological stress in obligate CYP21A2 mutation carriers, i.e, parents of children with $\mathrm{CAH}$. We used the birth or diagnosis of an affected child as the stressor, and investigated whether CYP21A2 carriers had an increased risk for psychiatric morbidity per se and after this stressful event. Parents of children with hypospadias or diabetes mellitus type 1 (T1DM), both situations known to be stressful for the parents and having comparable aspects were used as controls. ${ }^{17,18}$

\section{Methods}

Subjects

The Swedish National CAH Registry comprises more than 600 individuals and has been described in detail elsewhere. ${ }^{3,19}$ A complete personal identification number was known for 545 of these patients born between 1910 and 2009, and the CYP21A2 genotype was known for more than $80 \%$. An additional 43 patients were identified through the National Patient Register and validated as previously reported. ${ }^{19}$ Altogether, 588 patients with a $21-$ 
hydroxylase deficiency were identified. All patients were anonymized by Statistics Sweden before the linkage to population based registers.

Parents of patients with CAH were identified through the Multigeneration Register. They were then divided into two groups based on the genotype or the clinical severity of the disease of the child. The parents of individuals with SW or SV CAH were assumed to carry a classic CYP21A2 mutation. The other group comprised parents of patients with NCAH who may carry either a classic mutation or a mutation that would predict NCAH in addition to the parents of patients with $\mathrm{CAH}$ of unknown severity. A total of 610 carriers were identified and divided into two groups comprising 240 carriers of classic mutations and 370 carriers of a mixture of mutations and of undetermined severity. Three control groups of parents matched for age were used: parents from the general population $(n=48,888)$, parents with a child diagnosed with hypospadias $(n=22,294)$, and parents with a child diagnosed with T1DM $(n=48,747)$

\section{Study protocol}

The prevalence of psychiatric diagnoses in the different groups of parents previous to the birth of an affected child was investigated. The birth or diagnosis of the affected child was used as the psychological stressor. Psychiatric diagnoses of the parents before and after the birth of an affected child were analysed. The selected psychiatric diagnoses in the National Patient Register were mood disorders (ICD-8 codes 296.1, 296.3, 296.8, 300.4; ICD-9 codes 296, 300E, 311; ICD-10 codes F30-F39), anxiety, dissociative, stress-related, somatoform, phobias or unspecified non-psychotic psychiatric diagnoses (ICD-8 code 300 except 300.4, code 307, ICD-9 code 300 except 300E, codes 306, 308-309; ICD-10 codes F40-F45, F48), eating disorders (ICD-9 codes 307B and 307F; ICD-10 code F50), mental and behavioral 
disorders due to psychoactive substance use (alcohol: ICD-8 codes 303; ICD-9 codes 303, 305A and 305X; ICD-10 codes F10; other drugs: ICD-8 codes 304; ICD-9 codes 304; ICD-10 codes F11-F19), and other behavioral emotional disorders with the onset usually occurring in childhood or adolescence (ICD-9 codes 312-313; ICD-10 codes F91-F98).

A matched control design was used employing three different control groups with parents matched for sex and year of birth: (i) parents of children in the general population before and after the birth of the child, (ii) parents of children with diabetes type 1 (T1DM) (250 in ICD8/ICD-9 and E10 in ICD-10) before and after the diagnosis of the child, and (iii) parents of children with hypospadias (752.2 in ICD-8, 752.61 in ICD-9 and Q54 in ICD-10) before and after the birth of the child. Descriptive statistics are shown in Tables 1. Despite using the national registries it was not possible to identify matched controls for all parents resulting in a small variation in the number of parents in the different groups.

All calculations were performed with and without controlling for the highest level of education reached by the parents. The educational level was designated as one of four different levels: primary and lower secondary school, upper secondary school, post-secondary school, postgraduate, or unknown level of education.

The study was approved by the Regional Ethical Review Board in Stockholm, Sweden.

\section{Statistical analysis}

The risk of psychiatric disorders was estimated by conditional logistic regression. Results were reported as Odds Ratios (ORs) and 95\% Confidence Intervals (95\%CI). The CYP21A2 carriers were compared with three different control groups as described above. 
Calculations were also performed as bivariate and multivariate analyses controlling for the level of education of the parents. All statistical analyses were conducted with SAS software (version 9.3; Cary, NC, USA).

\section{Results}

There was a decreased risk of receiving any type of psychiatric diagnosis when the total number of parents of children with $\mathrm{CAH}$, regardless of severity, was analysed and compared with the controls groups before the birth or diagnosis of the child (Table 2). On breaking down the analysis into different diagnoses, a difference in mood and anxiety disorders persisted compared to the general population and to parents of a child with hypospadias. After adjusting for the educational level, the difference remained statistically significant for any type of psychiatric disorder compared to all three control groups and for mood disorder compared to the general population, as well as for anxiety disorders compared to parents with hypospadias. As seen in Table 3, after the birth of the child the risk of receiving any psychiatric diagnosis and of suicide, mood disorder, anxiety, substance misuse, or stress disorder was decreased for the CYP21A2 carriers in all comparison groups except for anxiety compared to T1DM (OR 0.3-0.8).

The parents of children with classic $\mathrm{CAH}$, i.e., obligate carriers of a classic, more severe, CYP21A2 mutations, were also analysed separately. The difference in the risk between the groups receiving any psychiatric diagnosis before the birth of the child only reached statistical significance when compared to parents with a child with hypospadias (Table 4). After the diagnosis of a child, there were significant differences indicating a lower risk of receiving several psychiatric diagnoses for the carriers (Table 5). The carriers of classic CYP21A2 mutations had a lesser risk of receiving any type of psychiatric diagnosis than parents in the 
general population (OR $0.6,95 \%$ CI $0.4-0.9, \mathrm{p}=0.014)$ or compared to a child with T1DM (OR $0.6,95 \%$ CI $0.4-0.9, \mathrm{p}=0.017$ ) or a child with hypospadias ( OR $0.6,95 \% \mathrm{CI} 0.4-0.9, \mathrm{p}=0.007)$. They were less likely to have a diagnosis of mood disorder/affective disorder after the diagnosis of the child, compared to the general population (OR $0.4,95 \% \mathrm{CI} 0.2-0.9, \mathrm{p}=0.0164$ ) or a child with hypospadias (OR $0.4,95 \%$ CI $0.2-0.8, \mathrm{p}=0.013)$. The carriers were less likely to develop substance misuse (including drugs and alcohol misuse) compared to all three control groups (OR 0.2-0.3, $\mathrm{p} \leqq 0.02)$. When analysed separately, alcohol misuse showed a significant difference compared to that of the parents with a child with T1DM and a tendency towards that of the general population or hypospadias. The difference for anxiety disorder was significant compared to the general population, but did not reach significance for the T1DM and hypospadias parents on controlling for educational level. The difference for the risk of committing suicide was significant compared with that for the general population without adjusting for education, but in no other comparisons.

Comparisons between the parents of children with NCAH or CAH of unknown severity, i.e., a mixture of carriers of both severe and milder CYP21A2 mutations, did not show significant differences in any of the parameters studied, only some tendencies, indicating that the severity of the mutation was important (data not shown).

Statistical calculations for parents of girls and boys with CAH separately did not show significant differences between the different parental groups (data not shown), most probably due to small sample sizes. The same was true when mothers and fathers of children with severe mutations were assessed separately, whereby only a few parameters showed significant differences (data not shown), most likely due to sample size. 


\section{Discussion}

This is the largest study investigating carriers of a $C Y P 21 A 2$ mutation and is derived from a population-based cohort. We found that obligate carriers, i.e., parents of patients with known $\mathrm{CAH}$, had a decreased risk of receiving a psychiatric diagnosis both per se, i.e., before and more markedly so after the birth of an affected child, regarded as a stressful event. The carriers were compared to three control groups: parents in the general population, parents of a child with T1DM, and parents of a child with hypospadias. These control groups were chosen to control for the type of stress that having a child with CAH may pose to the parents. The birth of a child with genital anomalies or even unclear sex at birth is a known psychological stressor, and posttraumatic stress disorders are increased among these parents. ${ }^{17,20}$ Hypospadias and $\mathrm{CAH}$ affect genital development and may lead to uncertainty of gender assignment at birth. ${ }^{17,21} \mathrm{CAH}$ and T1DM are both potentially life-threatening diseases ${ }^{21,22}$ that require daily treatment and extra attention from the parents, something that is well known to be stressful.

In order to investigate whether the severity of the mutation was important, we analysed the parents who were obligate carriers of classic and less severe CYP21A2 mutations separately. Those who were carriers of a severe mutation had a lower risk of developing any psychiatric diagnosis after the birth of the affected child than parents from any of the three control groups. In addition, they had a decreased risk of being diagnosed with an affective disorder or substance misuse. Moreover, suicides were less prevalent in carriers, significantly so compared to general population. These effects were only seen for carriers of severe, i.e., classic CYP21A2 mutations and not for the group with unknown and milder mutations. 
We interpret our results to show the carriers to be less vulnerable to the psychologically stressful situation of having a child with a severe diagnosis, possibly because of an increased psychological resilience. It is not possible to decipher the mechanism for this in this type of epidemiological study, but it can be speculated that it is associated with adaptive changes in the HPA axis or mechanisms involving locus coeruleus, the monoaminergic system, or the amygdala via CRH effects. $^{12,13}$

Impairments in the function of the HPA axis, e.g., as a result of chronic stress, are known to be important in the development of depression owing to a hyperactive HPA axis with elevated basal cortisol levels, disrupted diurnal cortisol secretion, and dysregulation in the HPA negative feedback system. ${ }^{12,23}$ Carriers of severe CYP21A2 mutations may be at decreased risk of developing affective disorders as a result of their prompt and more elevated response to ACTH. ${ }^{4}$ This may facilitate a more efficient return to homeostasis via a more effective feedback inhibition of cortisol on supra-hypothalamic, hypothalamic, and/or pituitary levels. ${ }^{4}$ The picture is complicated, however, by the positive feed-forward mechanism where glucocorticoids further enhance CRH activity and behavioral responses to stress ${ }^{24}$ that would result in the opposite.

Interestingly, our findings are in contrast with the previous suggestion that $C Y P 21 A 2$ carriers are at increased risk of affective and anxiety disorders. The study by Charmandari et al. ${ }^{5}$ was conducted on a small group of individuals but consisted of both psychological assessments and biochemical laboratory investigations including $\mathrm{CRH}$ stimulation. They saw no difference when the carriers and controls were compared on a group level, but correlations with the results of the different psychometric tests differed for the carriers and the healthy controls. An increased cortisol excretion correlated with more stress and anxiety in the controls, something 
that could be expected in stressful circumstances. The study had a considerable exclusion rate of $50 \%$. The carriers were excluded for somatic or psychiatric reasons. CRH stimulation gave an area under the curve for ACTH that was larger in carriers than in controls, but the cortisol response showed no difference. Not surprisingly, the carriers had a larger area under the curve for 17-OHP.

We used psychiatric diagnoses as a proxy or indicator for vulnerability to psychological stressors. By virtue of the study design, only associations can be identified, but not causal factors for the decreased risk for psychiatric morbidity. However, all comparisons point in the same direction, i.e., a lower risk of a psychiatric disorder whether related to stress, mood, anxiety, or suicide. Unfortunately, we were not able to specifically analyse obsessivecompulsive disorder, stress-related disorders (e.g., PTSD) because of the low number of patients with the diagnosis. ${ }^{25}$ Our results point rather to a tendency towards a lower probability of receiving a diagnosis of anxiety in obligate carriers of a severe $C Y P 21 A 2$ mutation. Unpredictable psychological stressors are more likely to result in depressive symptoms than predictable stressors. ${ }^{26}$ Is it possible that the exaggerated increase in the ACTH response is of greater importance than a smaller increase in CRH over time.

The strengths of the study are that it covers a population-based cohort, implying no selection bias. The CAH Registry covers virtually all patients in Sweden and the National Patient Register used for controls and for the psychiatric diagnosis has full coverage since 1964 for hospital care and from 2001 for out-patient care. The CAH diagnosis was validated in the Registry, which was the basis for this epidemiological registry study using de-identified data, thus it is unlikely that patients were misdiagnosed. Less than $1 \%$ of $\mathrm{CAH}$ patients have a 
spontaneously occurring mutation, i.e., one of the parents is not a carrier, but since this is a rare event, and therefore unlikely to affect our results.

This study also provides interesting clues to our previous finding that psychiatric morbidity, more specifically substance misuse, anxiety, and mood disorders, is increased among patients, both men and women with $\mathrm{CAH}^{27,28}$ Since there is high heritability for these psychiatric diseases, the finding that parents to patients with $\mathrm{CAH}$ have a decreased risk for psychiatric disorders suggests that the increased risk for psychiatric morbidity in patients with CAH is less likely to be genetically or socially determined. Hence, other factors related to the disease situation (e.g., psychological ones) are involved.

In conclusion, our findings imply that $C Y P 21 A 2$ carriers have a decreased risk of any psychiatric diagnosis, especially affective and anxiety disorders. We compared parents of children with $\mathrm{CAH}$, hypospadias, T1DM, and the general population and found that obligate CYP21A2 carriers seemed to be less vulnerable to the psychologically stressful situation of having a child with a chronic disease. This indicates a better ability to cope with psychological stress among heterozygous carriers of CYP21A2 mutations, which may contribute to a survival advantage and the relatively high incidence of $C Y P 21 A 2$ carriers seen worldwide. A possible advantage with respect to somatic stress related disorders needs to be investigated.

\section{Acknowledgments}

This work was supported by Karolinska Institutet, the Stockholm County Council, the Swedish Research Council, Sällskapet Barnavård Foundation, the Stiftelsen Frimurare Barnhuset Foundation. We also acknowledge financial support from the Swedish Research 
Council through the Swedish Initiative for research on Microdata in the Social and Medical sciences (SIMSAM) framework grant no. 340-2013-5867.

\section{References}

1. Speiser PW, Azziz R, Baskin LS, et al. Congenital adrenal hyperplasia due to steroid 21hydroxylase deficiency: an Endocrine Society clinical practice guideline. J Clin Endocrinol Metab. 2010; 95(9): 4133-60.

2. Speiser PW, Dupont B, Rubinstein P, Piazza A, Kastelan A, New MI. High frequency of nonclassical steroid 21-hydroxylase deficiency. Am J Hum Genet. 1985;37(4):650-67.

3. Gidlöf S, Falhammar H, Thilén A, von Döbeln A, Ritzén M, Wedell A, Nordenström A. One hundred years of congenital adrenal hyperplasia in Sweden: a retrospective, populationbased cohort study. The Lancet Diabetes \& Endocrinology 2013;1(1): 35-43.

4. Witchel SF, Lee PA, Suda-Hartman M, Trucco M, Hoffman EP. Evidence for a heterozygote advantage in congenital adrenal hyperplasia due to 21-hydroxylase deficiency. J Clin Endocrinol Metab. 1997;82(7):2097-101.

5. Charmandari E, Merke DP, Negro PJ, Keil MF, Martinez PE, Haim A, Gold PW, Chrousos GP. Endocrinologic and psychologic evaluation of 21-hydroxylase deficiency carriers and matched normal subjects: evidence for physical and/or psychologic vulnerability to stress. J Clin Endocrinol Metab. 2004;89(5):2228-36.

6. Livadas S, Dracopoulou M, Lazaropoulou C, Papassotiriou I, Sertedaki A, Angelopoulos GN, Chrousos GP, Dacou-Voutetakis C. A favorable metabolic and antiatherogenic profile in carriers of CYP21A2 gene mutations supports the theory of a survival advantage in this population. Horm Res. 2009;72(6):337-43. 
7. Falhammar H, Nordenström A. Nonclassic congenital adrenal hyperplasia due to 21hydroxylase deficiency: clinical presentation, diagnosis, treatment, and outcome. Endocrine. 2015;50(1):32-50.

8. Wedell A, Ritzén EM, Haglund-Stengler B, Luthman H. Steroid 21-hydroxylase deficiency: three additional mutated alleles and establishment of phenotype-genotype relationships of common mutations. Proc Natl Acad Sci U S A. 1992;89(15):7232-6.

9. Krone N, Rose IT, Willis DS, Hodson J, Wild SH, Doherty EJ, Hahner S, Parajes S, Stimson RH, Han TS, Carroll PV, Conway GS, Walker BR, MacDonald F, Ross RJ, Arlt W; United Kingdom Congenital adrenal Hyperplasia Adult Study Executive (CaHASE). Genotype-phenotype correlation in 153 adult patients with congenital adrenal hyperplasia due to 21-hydroxylase deficiency: analysis of the United Kingdom Congenital adrenal Hyperplasia Adult Study Executive (CaHASE) cohort. J Clin Endocrinol Metab. 2013;98(2):E346-54.

10. Falhammar H, Wedell A, Nordenström A. Biochemical and genetic diagnosis of 21hydroxylase deficiency. Endocrine. 2015;50(2):306-14

11. New MI, Speiser PW. Genetics of adrenal steroid 21-hydroxylase deficiency. Endocr Rev. 1986;7(3):331-49. Review.

12. Nicolaides NC, Kyratzi E, Lamprokostopoulou A, Chrousos GP, Charmandari E. Stress, the stress system and the role of glucocorticoids. Neuroimmunomodulation. 2015;22(1-2):6-19.

13. Tsigos C, Chrousos GP. Hypothalamic-pituitary-adrenal axis, neuroendocrine factors and stress. J Psychosom Res. 2002;53(4):865-71. Review.

14. Gold PW. The organization of the stress system and its dysregulation in depressive illness. Mol Psychiatry. 2015;20 (1):32-47.

15. Reeves JW, Fisher AJ, Newman MG, Granger DA. Sympathetic and hypothalamic- 
pituitary-adrenal asymmetry in generalized anxiety disorder. Psychophysiology. 2016, Mar 2, doi: 10.1111/psyp.12634

16. Dieleman GC, Huizink AC, Tulen JH, Utens EM, Creemers HE, van der Ende J, Verhulst FC. Alterations in HPA-axis and autonomic nervous system functioning in childhood anxiety disorders point to a chronic stress hypothesis. Psychoneuroendocrinology. 2015;51:135-50

17. Pasterski V, Mastroyannopoulou K, Wright D, Zucker KJ, Hughes IA. Predictors of posttraumatic stress in parents of children diagnosed with a disorder of sex development. Arch Sex Behav. 2014;43(2):369-75.

18. Duguid A, Morrison S, Robertson A, Chalmers J, Youngson G, Ahmed SF; Scottish Genital Anomaly Network. The psychological impact of genital anomalies on the parents of affected children. Acta Paediatr. 2007;96(3):348-52.

19. Strandqvist A, Falhammar H, Lichtenstein P, et al. Suboptimal psychosocial outcomes in patients with congenital adrenal hyperplasia: epidemiological studies in a nonbiased national cohort in Sweden. J Clin Endocrinol Metab. 2014;99(4):1425-32.

20. Fedele DA, Kirk K, Wolfe-Christensen C, Phillips TM, Mazur T, Mullins LL, Chernausek SD, Wisniewski AB. Primary caregivers of children affected by disorders of sex development: mental health and caregiver characteristics in the context of genital ambiguity and genitoplasty. Int J Pediatr Endocrinol. 2010;2010:690674. doi: 10.1155/2010/690674.

21. Kirk KD, Fedele DA, Wolfe-Christensen C, Phillips TM, Mazur T, Mullins LL, Chernausek SD, Wisniewski AB. Parenting characteristics of female caregivers of children affected by chronic endocrine conditions: a comparison between disorders of sex development and type 1 diabetes mellitus. J Pediatr Nurs. 2011;26(6):e29-36.

22. Falhammar H, Frisén L, Norrby C, Hirschberg AL, Almqvist C, Nordenskjöld A, Nordenström A. Increased mortality in patients with congenital adrenal hyperplasia due to 21hydroxylase deficiency. J Clin Endocrinol Metab. 2014;99(12):E2715-21 
23. Swaab DF, Bao AM, Lucassen PJ. The stress system in the human brain in depression and neurodegeneration. Ageing Res Rev. 2005 May;4(2):141-94.

24. Habib KE, Weld KP, Rice KC, Pushkas J, Champoux M, Listwak S, Webster EL, Atkinson AJ, Schulkin J, Contoreggi C, Chrousos GP, McCann SM, Suomi SJ, Higley JD, Gold PW. Oral administration of a corticotropin-releasing hormone receptor antagonist significantly attenuates behavioral, neuroendocrine, and autonomic responses to stress in primates. Proc Natl Acad Sci U S A. 2000;97(11):6079-84.

25. Coryell WH, Black DW, Kelly MW, Noyes R Jr. HPA axis disturbance in obsessivecompulsive disorder Psychiatry Res. 1989;30(3):243-51.

26. Havranek MM, Bolliger B, Roos S, Pryce CR, Quednow BB, Seifritz E. Uncontrollable and unpredictable stress interacts with subclinical depression and anxiety scores in determining anxiety response. Stress. 2016;19(1):53-62.

27. Engberg H, Butwicka A, Nordenström A, Hirschberg AL, Falhammar H, Lichtenstein P, Nordenskjöld A, Frisén L, Landén M. Congenital adrenal hyperplasia and risk for psychiatric disorders in girls and women born between 1915 and 2010: A total population study. Psychoneuroendocrinology. 2015;60:195-205.

28. Falhammar H, Butwicka A, Landen M, et al. Increased psychiatric morbidity in men with congenital adrenal hyperplasia due to 21-hydroxylase deficiency. J Clin Endocrinol Metab. 2014;99(3): E554-60. 
Table 1: Descriptive statistics for parents of children with CAH and their matched controls from general population, parents of children with type 1 diabetes or hypospadias.

\begin{tabular}{|c|c|c|c|c|c|c|}
\hline & \multicolumn{2}{|l|}{ Comparison 1} & \multicolumn{2}{|l|}{ Comparison 2} & \multicolumn{2}{|l|}{ Comparison 3} \\
\hline & Probands & Controls & Probands & Controls & Probands & Controls \\
\hline Characteristic & $\begin{array}{l}\text { Parents of children } \\
\text { with CAH } \\
N=610 \quad n(\%)\end{array}$ & $\begin{array}{l}\text { Parents from } \\
\text { general population } \\
N=48,888 \\
n(\%)\end{array}$ & $\begin{array}{l}\text { Parents of children } \\
\text { with CAH } \\
N=606 n(\%)\end{array}$ & $\begin{array}{l}\text { Parents of child } \\
\text { with T1DM } \\
\begin{array}{l}N=48,747 \\
n(\%)\end{array}\end{array}$ & $\begin{array}{l}\text { Parents of children } \\
\text { with CAH } \\
N=577 n(\%)\end{array}$ & $\begin{array}{l}\text { Parents of child } \\
\text { with hypospadias } \\
N=22,294 \\
n(\%)\end{array}$ \\
\hline \multicolumn{7}{|l|}{ Sex } \\
\hline Male & 297 (48.7) & $10404(21.3)$ & $305(50.3)$ & $37658(77.3)$ & $281(48.7)$ & $10820(48.5)$ \\
\hline Female & $313(51.3)$ & 38484 (78.7) & $301(49.7)$ & $11089(22.7)$ & $296(51.3)$ & $11474(51.5)$ \\
\hline \multicolumn{7}{|l|}{ Age at child birth (yrs) } \\
\hline$<35$ & $489(80.2)$ & $41810(85.5)$ & $485(80.0)$ & $38294(78.6)$ & $475(82.3)$ & $17387(78.0)$ \\
\hline$\geq 35$ & $121(19.2)$ & $7078(14.5)$ & $121(20 \cdot 0)$ & $10453(21.4)$ & $102(17.7)$ & $4907(22.0)$ \\
\hline \multicolumn{7}{|l|}{ Education } \\
\hline $\begin{array}{l}\text { Primary and lower } \\
\text { secondary }\end{array}$ & $125(20.5)$ & $11292(23.0)$ & $123(20.3)$ & $11621(23.8)$ & $112(19.4)$ & $4769(21.4)$ \\
\hline Upper secondary & $248(40.7)$ & $21300(43.6)$ & $247(40.8)$ & $21804(44.7)$ & $245(42.5)$ & $10052(45.0)$ \\
\hline Post-secondary & $73(12.0)$ & $6006(12.3)$ & $73(12.0)$ & $5357(11.0)$ & $72(12.5)$ & $2777(12.5)$ \\
\hline Postgraduate & $148(24.2)$ & $8984(18.4)$ & $148(24.4)$ & $8075(16.5)$ & $140(24.2)$ & $4315(19.4)$ \\
\hline Unknown & $16(2.6)$ & $1306(2.7)$ & $15(2.5)$ & $1890(3.9)$ & $8(1.4)$ & $381(1.7)$ \\
\hline
\end{tabular}


Table 2. Odds ratios (with 95\% confidence interval) and p-values for receiving a psychiatric diagnosis before the childbirth in parents of children with all types of CAH compared to matched parents of a child from the general population, parents of a child with type 1 diabetes or parents of a child with hypospadias.

\begin{tabular}{|c|c|c|c|c|c|c|c|c|c|c|c|c|}
\hline \multirow{4}{*}{$\begin{array}{l}\text { Psychiatri } \\
\text { c disorder }\end{array}$} & \multicolumn{6}{|c|}{ Bivariate analysis } & \multicolumn{6}{|c|}{ Multivariate analysis \# } \\
\hline & \multicolumn{6}{|c|}{ Control group } & \multicolumn{6}{|l|}{ Control group } \\
\hline & \multicolumn{2}{|c|}{$\begin{array}{l}\text { Parents from } \\
\text { general population }\end{array}$} & \multicolumn{2}{|c|}{$\begin{array}{l}\text { Parents of child } \\
\text { with T1DM }\end{array}$} & \multicolumn{2}{|c|}{$\begin{array}{l}\text { Parents of child } \\
\text { with hypospadias }\end{array}$} & \multicolumn{2}{|c|}{$\begin{array}{l}\text { Parents from general } \\
\text { population }\end{array}$} & \multicolumn{2}{|c|}{$\begin{array}{l}\text { Parents of child with } \\
\text { T1DM }\end{array}$} & \multicolumn{2}{|c|}{$\begin{array}{l}\text { Parents of child with } \\
\text { hypospadias }\end{array}$} \\
\hline & $\begin{array}{l}\text { Crude OR } \\
(95 \% \mathrm{CI})\end{array}$ & $\mathbf{p}$ & $\begin{array}{l}\text { Crude OR } \\
(95 \% \mathrm{CI})\end{array}$ & $\mathbf{p}$ & $\begin{array}{l}\text { Crude OR } \\
(95 \% \mathrm{CI})\end{array}$ & $\mathbf{p}$ & $\begin{array}{l}\text { Adjusted OR } \\
(95 \% \mathrm{CI})\end{array}$ & $\mathbf{p}$ & $\begin{array}{l}\text { Adj OR } \\
(95 \% \mathrm{CI})\end{array}$ & $\mathbf{p}$ & $\begin{array}{l}\text { Adj OR } \\
(95 \% \mathrm{CI})\end{array}$ & $\mathbf{p}$ \\
\hline $\begin{array}{l}\text { Any } \\
\text { psychiatric } \\
\text { diagnosis }\end{array}$ & $0.5(0.3-0.9)$ & 0.016 & $0.4(0.2-0.8)$ & 0.015 & $0.4(0.2-0.8)$ & 0.006 & $0.5(0.3-0.9)$ & 0.020 & $0.5(0.2-0.9)$ & 0.019 & $0.4(0.2-0.8)$ & 0.008 \\
\hline Suicide & $0.7(0.3-1.6)$ & 0.387 & $1.0(0.4-2.2)$ & 0.943 & $0.7(0.3-1.6)$ & 0.422 & $0.7(0.3-1.6)$ & 0.406 & $1.0(0.5-2.3)$ & 0.918 & $0.8(0.3-1.7)$ & 0.491 \\
\hline $\begin{array}{l}\text { Mood } \\
\text { disorder }\end{array}$ & $0.1(0.0-0.9)$ & 0.044 & $0.2(0.0-1.6)$ & 0.131 & $0.2(0.0-1.1)$ & 0.061 & $0.1(0.0-1.0)$ & 0.046 & $0.2(0.0-1.6)$ & 0.130 & $0.2(0.0-1.1)$ & 0.061 \\
\hline Anxiety & $0.4(0.1-1.0)$ & 0.056 & $0.4(0.1-1.1)$ & 0.084 & $0.4(0.1-1.0)$ & 0.040 & $0.4(0.1-1.0)$ & 0.058 & $0.4(0.1-1.2)$ & 0.101 & $0.4(0.1-1.0)$ & 0.048 \\
\hline $\begin{array}{l}\text { Substance } \\
\text { misuse }\end{array}$ & $0.6(0.2-1.7)$ & 0.363 & $0.4(0.1-1.4)$ & 0.157 & $0.6(0.2-1.5)$ & 0.265 & $0.7(0.2-1.8)$ & 0.408 & $0.5(0.2-1.5)$ & 0.201 & $0.6(0.2-1.6)$ & 0.323 \\
\hline $\begin{array}{l}\text { Drug } \\
\text { Misuse } \\
\end{array}$ & $0.3(0.0-2.5)$ & 0.290 & $0.3(0.0-2.4)$ & 0.271 & $0.4(0.0-2.5)$ & 0.301 & $0.4(0.1-2.6)$ & 0.312 & $0.4(0.1-2.6)$ & 0.310 & $\dagger$ & \\
\hline $\begin{array}{l}\text { Alcohol } \\
\text { misuse }\end{array}$ & $0.7(0.2-2.1)$ & 0.479 & $0.4(0.1-1.7)$ & 0.225 & $0.6(0.2-1.9)$ & 0.384 & $0.7(0.2-2.2)$ & 0.527 & $0.5(0.1-1.9)$ & 0.277 & $0.6(0.2-2.0)$ & 0.444 \\
\hline $\begin{array}{l}\text { Stress } \\
\text { disorder }\end{array}$ & $0.4(0.1-1.6)$ & 0.187 & $0.2(0.0-1.4)$ & 0.112 & $0.3(0.1-1.2)$ & 0.084 & $0.4(0.1-1.6)$ & 0.188 & $0.2(0.0-1.6)$ & 0.130 & $0.3(0.1-1.2)$ & 0.089 \\
\hline
\end{tabular}

\# Adjustment for education. $\uparrow$-Values for this OR and $95 \%$ CI were not possible to calculate due to zero values. Bold values indicate $\mathrm{P}<0$.05. Italic values indicate $\mathrm{P}=0.05-0.099$ 
Table 3: Odds ratios (with 95\% confidence interval) and $\mathrm{p}$ values for receiving a psychiatric diagnosis after the childbirth in parents of children with all types of CAH compared to matched parents of a child from the general population, parents of a child with type 1 diabetes or parents of a child with hypospadias.

\begin{tabular}{|c|c|c|c|c|c|c|c|c|c|c|c|c|}
\hline \multirow{4}{*}{$\begin{array}{l}\text { Psychiatri } \\
\text { c disorder }\end{array}$} & \multicolumn{6}{|c|}{ Bivariate analysis } & \multicolumn{6}{|c|}{ Multivariate analysis \# } \\
\hline & \multicolumn{6}{|c|}{ Control group } & \multicolumn{6}{|l|}{ Control group } \\
\hline & \multicolumn{2}{|c|}{$\begin{array}{l}\text { Parents from } \\
\text { general population }\end{array}$} & \multicolumn{2}{|c|}{$\begin{array}{l}\text { Parents of child } \\
\text { with T1DM }\end{array}$} & \multicolumn{2}{|c|}{$\begin{array}{l}\text { Parents of child with } \\
\text { hypospadias }\end{array}$} & \multicolumn{2}{|c|}{$\begin{array}{l}\text { Parents from general } \\
\text { population }\end{array}$} & \multicolumn{2}{|c|}{$\begin{array}{l}\text { Parents of child with } \\
\text { T1DM }\end{array}$} & \multicolumn{2}{|c|}{$\begin{array}{l}\text { Parents of child with } \\
\text { hypospadias }\end{array}$} \\
\hline & $\begin{array}{l}\text { Crude OR } \\
(95 \% \mathrm{CI})\end{array}$ & $\mathbf{p}$ & $\begin{array}{l}\text { Crude OR } \\
(95 \% \mathrm{CI})\end{array}$ & $\mathbf{p}$ & $\begin{array}{l}\text { Crude OR } \\
(95 \% \mathrm{CI})\end{array}$ & $\mathbf{p}$ & $\begin{array}{l}\text { Adjusted OR } \\
(95 \% \mathrm{CI})\end{array}$ & $\mathbf{p}$ & $\begin{array}{l}\text { Adjusted } \\
\text { OR }(95 \% \\
\text { CI) }\end{array}$ & $\mathbf{p}$ & $\begin{array}{l}\text { Adj OR } \\
(95 \% \mathrm{CI})\end{array}$ & $\mathbf{p}$ \\
\hline $\begin{array}{l}\text { Any } \\
\text { psychiatric } \\
\text { diagnosis }\end{array}$ & $0.7(0.5-0.9)$ & 0.017 & $0.8(0.6-1.0)$ & 0.043 & $0.7(0.5-1.0)$ & 0.024 & $0.7(0.6-1.0)$ & $\mathbf{0 . 0 3 4}$ & $0.8(0.6-1.0)$ & 0.091 & $0.7(0.6-1.0)$ & 0.042 \\
\hline Suicide & $0.3(0.1-0.8)$ & 0.014 & $0.3(0.1-0.9)$ & 0.030 & $0.2(0.0-0.7)$ & 0.014 & $0.3(0.1-0.8)$ & 0.018 & $0.4(0.1-1.0)$ & 0.043 & $0.2(0.0-0.7)$ & 0.016 \\
\hline $\begin{array}{l}\text { Mood } \\
\text { disorder }\end{array}$ & $0.6(0.4-0.9)$ & 0.022 & $0.8(0.5-1.2)$ & 0.321 & $0.5(0.3-0.9)$ & 0.016 & $0.6(0.4-1.0)$ & 0.031 & $0.8(0.5-1.3)$ & 0.381 & $0.5(0.3-0.9)$ & $\mathbf{0 . 0 2 0}$ \\
\hline Anxiety & $0.6(0.4-0.9)$ & 0.016 & $0.7(0.5-1.1)$ & 0.173 & $0.6(0.4-0.9)$ & 0.021 & $0.6(0.4-0.9)$ & 0.024 & $0.8(0.5-1.2)$ & 0.228 & $0.6(0.4-1.0)$ & 0.034 \\
\hline $\begin{array}{l}\text { Substance } \\
\text { misuse }\end{array}$ & $0.5(0.2-0.9)$ & 0.020 & $0.3(0.2-0.7)$ & 0.002 & $0.5(0.2-0.9)$ & 0.024 & $0.5(0.2-0.9)$ & $\mathbf{0 . 0 3 0}$ & $0.4(0.2-0.7)$ & 0.003 & $0.5(0.3-0.9)$ & $\mathbf{0 . 0 3 4}$ \\
\hline $\begin{array}{l}\text { Drug } \\
\text { Misuse }\end{array}$ & $0.2(0.1-1.0)$ & 0.046 & $0.3(0.1-1.0)$ & 0.056 & $0.3(0.1-1.1)$ & 0.059 & $0.3(0.1-1.0)$ & 0.056 & $0.3(0.1-1.1)$ & 0.070 & $0.3(0.1-1.1)$ & 0.067 \\
\hline $\begin{array}{l}\text { Alcohol } \\
\text { misuse }\end{array}$ & $0.5(0.3-1.1)$ & 0.089 & $0.4(0.2-0.8)$ & 0.007 & $0.6(0.3-1.2)$ & 0.146 & $0.6(0.3-1.2)$ & 0.121 & $0.4(0.2-0.8)$ & 0.013 & $0.6(0.3-1.3)$ & 0.186 \\
\hline $\begin{array}{l}\text { Stress } \\
\text { disorder }\end{array}$ & $0.4(0.2-0.9)$ & 0.022 & $0.5(0.2-1.0)$ & 0.047 & $0.4(0.2-0.8)$ & 0.011 & $0.5(0.2-0.9)$ & 0.028 & $0.5(0.3-1.0)$ & 0.062 & $0.4(0.2-0.8)$ & 0.015 \\
\hline
\end{tabular}

\# Adjustment for education. $\dagger$-Values for this OR and $95 \%$ CI were not possible to calculate due to zero values. Bold values indicate $\mathrm{P}<0$.05. Italic values

indicate $\mathrm{P}=0.05-0.099$. 
Table 4: Odds ratios (with 95\% confidence interval) and $\mathrm{p}$ values for receiving a psychiatric diagnosis before the childbirth in parents of children with classic form of CAH (i.e. carriers of a severe CYP21A2 mutation) compared to matched parents of a child from the general population, parents of a child with type 1 diabetes or parents of a child with hypospadias.

\begin{tabular}{|c|c|c|c|c|c|c|c|c|c|c|c|c|}
\hline \multirow{4}{*}{$\begin{array}{l}\text { Psychiat } \\
\text { ric } \\
\text { disorder }\end{array}$} & \multicolumn{6}{|c|}{ Bivariate analysis } & \multicolumn{6}{|c|}{ Multivariate analysis \# } \\
\hline & \multicolumn{6}{|c|}{ Control group } & \multicolumn{6}{|l|}{ Control group } \\
\hline & \multicolumn{2}{|c|}{$\begin{array}{l}\text { Parents from } \\
\text { general population }\end{array}$} & \multicolumn{2}{|c|}{$\begin{array}{l}\text { Parents of child with } \\
\text { T1DM }\end{array}$} & \multicolumn{2}{|c|}{$\begin{array}{l}\text { Parents of child } \\
\text { with hypospadias }\end{array}$} & \multicolumn{2}{|c|}{$\begin{array}{l}\text { Parents from general } \\
\text { population }\end{array}$} & \multicolumn{2}{|c|}{$\begin{array}{l}\text { Parents of child } \\
\text { with T1DM }\end{array}$} & \multicolumn{2}{|c|}{$\begin{array}{l}\text { Parents of child with } \\
\text { hypospadias }\end{array}$} \\
\hline & $\begin{array}{l}\text { Crude OR } \\
(95 \% \mathrm{CI})\end{array}$ & $\mathbf{p}$ & $\begin{array}{l}\text { Crude OR } \\
(95 \% \mathrm{CI})\end{array}$ & $\mathbf{p}$ & $\begin{array}{l}\text { Crude OR } \\
(95 \% \mathrm{CI})\end{array}$ & $\mathbf{p}$ & $\begin{array}{l}\text { Adj OR (95\% } \\
\text { CI) }\end{array}$ & $\mathbf{p}$ & $\begin{array}{l}\text { Adj OR } \\
(95 \% \mathrm{CI})\end{array}$ & $\mathbf{p}$ & $\begin{array}{l}\text { Adj OR } \\
(95 \% \mathrm{CI})\end{array}$ & $\mathbf{p}$ \\
\hline $\begin{array}{l}\text { Any } \\
\text { psychiatri } \\
\text { c }\end{array}$ & $0.5(0.3-1.1)$ & 0.079 & $0.5(0.2-1.0)$ & 0.056 & $0.5(0.2-1.0)$ & $\mathbf{0 . 0 3 9}$ & $0.5(0.3-1.1)$ & 0.088 & $0.5(0.2-1.1)$ & 0.069 & $0.5(0.2-1.0)$ & 0.047 \\
\hline Suicide & $0.7(0.3-1.9)$ & 0.513 & $1.1(0.4-2.9)$ & 0.909 & $0.8(0.3-2.0)$ & 0.581 & $0.7(0.3-2.0)$ & 0.529 & $1.2(0.4-3.1)$ & 0.781 & $0.8(0.3-2.2)$ & 0.662 \\
\hline $\begin{array}{l}\text { Mood } \\
\text { disorder }\end{array}$ & $0.2(0.0-1.5)$ & 0.113 & $0.3(0.0-2.3)$ & 0.253 & $0.2(0.0-1.6)$ & 0.131 & $0.2(0.0-1.5)$ & 0.118 & $0.3(0.0-2.3)$ & 0.251 & $0.2(0.0-1.6)$ & 0.132 \\
\hline Anxiety & $0.5(0.1-1.4)$ & 0.181 & $0.4(0.1-1.5)$ & 0.172 & $0.4(0.1-1.3)$ & 0.116 & $0.5(0.1-1.4)$ & 0.185 & $0.4(0.1-1.6)$ & 0.206 & $0.4(0.1-1.3)$ & 0.141 \\
\hline $\begin{array}{l}\text { Substanc } \\
\text { e misuse }\end{array}$ & $0.7(0.2-2.3)$ & 0.597 & $0.5(0.1-1.8)$ & 0.268 & $0.5(0.2-1.7)$ & 0.292 & $0.7(0.2-2.3)$ & 0.617 & $0.5(0.1-2.0)$ & 0.321 & $0.6(0.2-1.8)$ & 0.361 \\
\hline $\begin{array}{l}\text { Drug } \\
\text { misuse }\end{array}$ & $0.5(0.1-3.9)$ & 0.545 & $0.5(0.1-3.3)$ & 0.441 & $0.4(0.1-3.1)$ & 0.410 & $0.6(0.1-4.0)$ & 0.559 & $0.5(0.1-3.7)$ & 0.509 & & \\
\hline $\begin{array}{l}\text { Alcohol } \\
\text { misuse }\end{array}$ & $0.7(0.2-2.7)$ & 0.574 & $0.4(0.0-2.5)$ & 0.300 & $0.5(0.1-2.1)$ & 0.349 & $0.7(0.2-2.8)$ & 0.597 & $0.4(0.1-2.7)$ & 0.336 & $0.6(0.1-2.3)$ & 0.414 \\
\hline $\begin{array}{l}\text { Stress } \\
\text { disorder }\end{array}$ & $0.3(0.0-2.3)$ & 0.250 & & 0.999 & $0.3(0.0-1.8)$ & 0.172 & $0.3(0.0-2.3)$ & 0.260 & - & 0.999 & $0.3(0.0-1.9)$ & 0.185 \\
\hline
\end{tabular}

\# Adjustment for education. $\uparrow$-Values for this OR and 95\% CI were not possible to calculate due to zero values. Bold values indicate $\mathrm{P}<0$.05. Italic values

indicate $\mathrm{P}=0.05-0.099$. 
Table 5: Odds ratios (with 95\% confidence interval) and $\mathrm{p}$ values for receiving a psychiatric diagnosis after the childbirth in parents of children with classic form of CAH (i.e. carriers of a severe CYP21A2 mutation) compared to matched parents of a child from the general population, parents of a child with type 1 diabetes or parents of a child with hypospadias.

\begin{tabular}{|c|c|c|c|c|c|c|c|c|c|c|c|c|}
\hline \multirow{4}{*}{$\begin{array}{l}\text { Psychiatri } \\
\text { c disorder }\end{array}$} & \multicolumn{6}{|c|}{ Bivariate analysis } & \multicolumn{6}{|c|}{ Multivariate analysis \# } \\
\hline & \multicolumn{6}{|c|}{ Control group } & \multicolumn{6}{|c|}{ Control group } \\
\hline & \multicolumn{2}{|c|}{$\begin{array}{l}\text { Parents from } \\
\text { general population }\end{array}$} & \multicolumn{2}{|c|}{$\begin{array}{l}\text { Parents of child } \\
\text { with T1DM }\end{array}$} & \multicolumn{2}{|c|}{$\begin{array}{l}\text { Parents of child with } \\
\text { hypospadias }\end{array}$} & \multicolumn{2}{|c|}{$\begin{array}{l}\text { Parents from } \\
\text { general population }\end{array}$} & \multicolumn{2}{|c|}{$\begin{array}{l}\text { Parents of child } \\
\text { with T1DM }\end{array}$} & \multicolumn{2}{|c|}{$\begin{array}{l}\text { Parents of child with } \\
\text { hypospadias }\end{array}$} \\
\hline & $\begin{array}{l}\text { Crude OR } \\
(95 \% \mathrm{CI})\end{array}$ & $\mathbf{p}$ & $\begin{array}{l}\text { Crude OR } \\
(95 \% \mathrm{CI})\end{array}$ & $\mathbf{p}$ & $\begin{array}{l}\text { Crude OR } \\
(95 \% \mathrm{CI})\end{array}$ & $\mathbf{p}$ & $\begin{array}{l}\text { Adj OR } \\
(95 \% \mathrm{CI})\end{array}$ & $\mathbf{p}$ & $\begin{array}{l}\text { Adj OR } \\
(95 \% \text { CI })\end{array}$ & $\mathbf{p}$ & $\begin{array}{l}\text { Adj OR } \\
(95 \% \text { CI })\end{array}$ & $\mathbf{p}$ \\
\hline $\begin{array}{l}\text { Any } \\
\text { psychiatric } \\
\text { diagnosis }\end{array}$ & $0.6(0.4-0.9)$ & 0.014 & $0.6(0.4-0.9)$ & 0.017 & $0.6(0.4-0.9)$ & 0.007 & $0.6(0.4-0.9)$ & 0.017 & $0.7(0.4-1.0)$ & $\mathbf{0 . 0 3 0}$ & $0.6(0.4-0.9)$ & 0.009 \\
\hline Suicide & $0.2(0.1-1.0)$ & 0.048 & $0.3(0.1-1.1)$ & 0.076 & $0.3(0.1-1.1)$ & 0.067 & $0.2(0.1-1.0)$ & 0.051 & $0.3(0.1-1.2)$ & 0.095 & $0.3(0.1-1.1)$ & 0.075 \\
\hline $\begin{array}{l}\text { Mood } \\
\text { disorder }\end{array}$ & $0.4(0.2-0.9)$ & 0.016 & $0.6(0.3-1.1)$ & 0.085 & $0.4(0.2-0.8)$ & 0.013 & $0.5(0.2-0.9)$ & 0.019 & $0.6(0.3-1.1)$ & 0.101 & $0.4(0.2-0.8)$ & 0.014 \\
\hline Anxiety & $0.5(0.3-0.9)$ & 0.022 & $0.6(0.3-1.1)$ & 0.105 & $0.5(0.3-0.9)$ & 0.026 & $0.5(0.3-0.9)$ & 0.027 & $0.6(0.3-1.2)$ & 0.135 & $0.4(0.1-1.1)$ & 0.078 \\
\hline $\begin{array}{l}\text { Substance } \\
\text { misuse }\end{array}$ & $0.3(0.1-0.8)$ & 0.020 & $0.2(0.1-0.6)$ & 0.005 & $0.2(0.1-0.7)$ & 0.014 & $0.3(0.1-0.8)$ & 0.022 & $0.2(0.1-0.7)$ & 0.007 & $0.2(0.1-0.8)$ & 0.016 \\
\hline $\begin{array}{l}\text { Drug } \\
\text { misuse }\end{array}$ & - & 0.999 & - & 0.999 & - & 0.999 & - & 0.999 & - & 0.999 & - & 0.999 \\
\hline $\begin{array}{l}\text { Alcohol } \\
\text { misuse }\end{array}$ & $0.4(0.1-1.1)$ & 0.075 & $0.3(0.1-0.8)$ & 0.018 & $0.3(0.1-1.1)$ & 0.067 & $0.4(0.1-1.1)$ & 0.082 & $0.3(0.1-0.8)$ & 0.024 & $0.4(0.1-1.1)$ & 0.078 \\
\hline $\begin{array}{l}\text { Stress } \\
\text { disorder }\end{array}$ & $0.3(0.1-0.8)$ & 0.023 & $0.3(0.1-0.9)$ & 0.039 & $0.3(0.1-0.8)$ & 0.018 & $0.3(0.1-0.9)$ & 0.027 & $0.3(0.1-1.0)$ & 0.048 & $0.3(0.1-0.8)$ & 0.020 \\
\hline
\end{tabular}

$\#$ Adjustment for education. $\uparrow$-Values for this OR and $95 \%$ CI were not possible to calculate due to zero values. Bold values indicate $\mathrm{P}<0$.05. Italic values

indicate $\mathrm{P}=0.05-0.099$. 